\title{
CITIES OF SLOVENIA TOMORROW ACCORDING TO REGIONAL DEVELOPMENT PLANS
}

\author{
Simon Kušar \\ University of Ljubljana, Faculty of Arts, Department of Geography, \\ Aškerčeva 2, 1000 Ljubljana, Slovenia \\ e-mail: simon.kusar@ff.uni-lj.si
}

\begin{abstract}
Regional planning is one of factors that influence the future development of cities. In Slovenia, regional development plans, which consist of regional development programs and subprograms, are in preparation for the time period that runs up to 2006. These programs shall have an important influence to the future functions of cities, their morphological structure, functional role and social processes within them. Additionally, regional and subregional centres may gain on their importance. Cities of Slovenia shall develop in accor-dance with the paradigm of sustainable development.
\end{abstract}

Key words: planning, regional planning, urban geography, future of cities, Slovenia

\section{INTRODUCTION}

A Man is constantly excited by the challenges of the future, which yields more questions and provides fewer answers. The future seems so intangible and yet very beautiful and seducing (Korelc, 2002).

The Slovenian philosopher Anton Trstenjak (1993) says that a Man may transcend himself by his openness to the future, which, according toTrstenjak, presents pure existential category. A Man, with his capability of foreseeing, may conquer new dimension, which allows him to transcend the entire living world on this planet, and rises above everyday experiences (Trstenjak, 1993).

Thinking about the future leads to a kind of paradox. Since future does not exist, it cannot be an object of observation (Sarre and Blowers, 1974). One never knows what the future may bring. However, a man, capable of acts, may actively participate at creating and shaping it (Korelc, 2002). The main reason of studying the future is, in fact, our wish to influence it (Sarre and Blowers, 1974). Trstenjak (1993) even discusses the Man's inclination to be capable of conquering and possessing the future step by step more successfully. 
Planning is not aimed to predict the future, instead, it is an action directed to the future (Davidoff and Reiner, 1973; Dror, 1973; Faludi, 1976; Friedmann, 1987, Sarre, 1974; Vrišer, 1987), and is capable of forecasting the results of its own actions (Campbell and Fainstein, 1996). Planning, based on prior experiences and analyses of current conditions, means preparing the plan of actions for the future, that aims at changing the existing stream of events, achieving postulated goals or preventing the occurrence of certain event that may cause problems (Campbell and Fainstein, 1996; Davidoff and Reiner, 1973; Dror, 1973; Friedmann, 1987; Vrišer, 1978). Planning also presents the foundation of controlling the future and is aimed at ensuring undisturbed operation of the Man's society, as well as providing its qualitative and quantitative growth (Faludi, 1976). Planning produces programs in order to achive the desired future (Sarre, 1974). Development programs entail criteria of managing such growth (Sarre and Blowers, 1974).

Regional planning is part of attempts aimed at better regulation of human society at the level of larger spatial units- regions, via harmonising the goals of economic and spatial development, social justness and protection of the environment (Campell and Fainstein, 1996)

In 1999, Slovenia has introduced new legislation on promotion of balanced regional development, which follows modern principles of regional planning in Europe. In the context of this, the regional development program stands as the main instrument of promoting balanced economic, social and spatial view of development, lessening differences in economic growth and at life opportunities between regions, preventing the formation of new problem regions, restoring settlements throughout the entire land of the Republic of Slovenia and promoting environmentally sound economies (Balanced Regional Development Act, 1999).

Each regional plan and/or program demonstrates significant influence on the processes in cities, to their inhabitants and on social, functional and morphological structure. Therefore, one may query about the influence of regional development programs and subprograms on the transformation of Slovenian cities up to 2006 when current program period expires. Similarly, one may query about the image of Slovenia's cities of tomorrow.

The answer on that query seems to be very important in light of the fact, that according to the latest data, more than $50 \%$ or 1.000 .000 of inhabitants live in 78 cities or urban settlements (Premzl, 1999). Due to urban dispersion, which is the result of current trends in the growth of cities, suburbs also shall be taken into account when analysing development programs (Sarre and Blowers, 1974). Taking into account not only citizens of urban cities, but also those living in suburbs, which are equipped as cities and where the standard of living is no lower, but rather higher than that in the cities, then, we may claim that according to Lah (1999) three quarters of Slovenians live in the urban environment.

\section{METHODS AND DEFINITIONS}

\section{Methods}

Rumination on geographical features of Slovenian cities in the near future is not based on the intuition on how should these cities look like upon existing developmental trends and at 
numerous global processes being in operation, neither on utopian ideas as to how these cities should have looked like, rather, it remains on the solid grounds of comparative analyses of real regional programs. Its content is in the frame of working tasks of urban geography that entail (Vresk, 2002): findings on spatial extension of cities, the expansion of cities and city-like way of living (urbanisation), definitions of city's functions, their morphological structure, functional role, social-spatial structure and processes, findings on the meaning and influence of cities in the space as well as the relations between cities.

Comparative analyses is followed by the synthesis, which summarises the above mentioned findings and defines the image of Slovenian cities of tomorrow.

Both, the analysis and the synthesis are on the abstract level, mainly due to the following two reasons:

1. The status of the city is not defined by the law in Slovenia (Premzl, 1999), therefore, it is difficult to define which cities are urban and which not;

2. Programs and subprograms, in most cases, do not define, which cities are anticipated to experience changes.

\section{The regional development plan}

The regional development plan (or program) is according to the Balanced Regional Development Act (1999) the basic document at the regional level, which entails developmental advantages of the region and financially evaluated programs and subprograms. Each regional development plan consists of the strategic and executive part. The strategic part includes: problem analyses for each sector separately and the region as a whole, definitions of developmental problems, priorities and goals, evaluation of necessary financial means, indicators for monitoring the progress while realising goals, etc. The executive part is comprised of the description of programs and subprograms and carriers of these programs, schedule of due dates of program implementation, financial plan and geographical region where these programs are to be carried out. Additionally, some frame projects through which subprograms are supposed to be realised are defined (Navodilo..., 2000).

Regional development plan has to be made in each of 12 statistical regions, which are functional territorial units for regional planning until the provinces as a second level of self governance are established. Territorial units, upon which the regional development plans are made, do not entirely correspond to frontiers of statistical regions. Balanced Regional Development Act (1999) allows frontier-zone municipalities of statistical regions to participate at creating the regional development plan of the neighbouring region. Preparati-on of regional development programs is handled by regional development agencies in co-operation with governmental and non-governmental organisations, municipalities, economic enterprises and other interested individuals (Navodilo..., 2000). 


\section{Statistical regions in Slovenia (NUTS III): Some facts and figures}

Table 1: Statistical regions in Slovenia: some basic figures

\begin{tabular}{|l|c|c|c|c|c|}
\hline \multicolumn{1}{|c|}{ Statistical region } & $\begin{array}{c}\text { \% of } \\
\text { national } \\
\text { territory }\end{array}$ & $\begin{array}{c}\text { \% of } \\
\text { national } \\
\text { population }\end{array}$ & $\begin{array}{c}\text { Density } \\
\text { (inh./km }{ }^{2} \text { ) }\end{array}$ & $\begin{array}{c}\% \text { of } \\
\text { national BDP } \\
\text { p.p. average }\end{array}$ & $\begin{array}{c}\% \text { of EU } \\
\text { BDP p.p. } \\
\text { average }\end{array}$ \\
\hline Gorenjska & 10.5 & 9.9 & 92 & 92 & 63 \\
\hline Goriška & 11.5 & 6 & 52 & 102 & 69 \\
\hline SE Slovenia & 13.2 & 6.9 & 52 & 91 & 62 \\
\hline Koroška & 5.1 & 3.7 & 71 & 87 & 59 \\
\hline Notranjsko-kraška & 7.2 & 2.5 & 35 & 85 & 59 \\
\hline Obalno-kraška & 5.2 & 5.2 & 100 & 105 & 71 \\
\hline Osrednjeslovenska* & 12.6 & 24.7 & 193 & 134 & 91 \\
\hline Podravska & 10.7 & 16 & 147 & 83 & 57 \\
\hline Pomurska & 6.6 & 6.2 & 93 & 77 & 52 \\
\hline Savinjska & 11.8 & 12.9 & 108 & 91 & 62 \\
\hline Spodnjeposavska & 4.4 & 3.5 & 79 & 84 & 57 \\
\hline Zasavska & 1.3 & 2.3 & 175 & 80 & 55 \\
\hline
\end{tabular}

* - Osrednjeslovenska (Central Slovene) statistical region (NUTS III) = Ljubljana urban region (NUTS II). Source: Pečar, J., 2002: Regionalni vidiki razvoja Slovenije (in poslovanje gospodarskih družb v letu 2001). Delovni zvezki Urada za makroekonomske analize in razvoj, letnik XI, št. 7, 159 str.

Figure 1: Statistical regions (NUTS 3) in Slovenia.

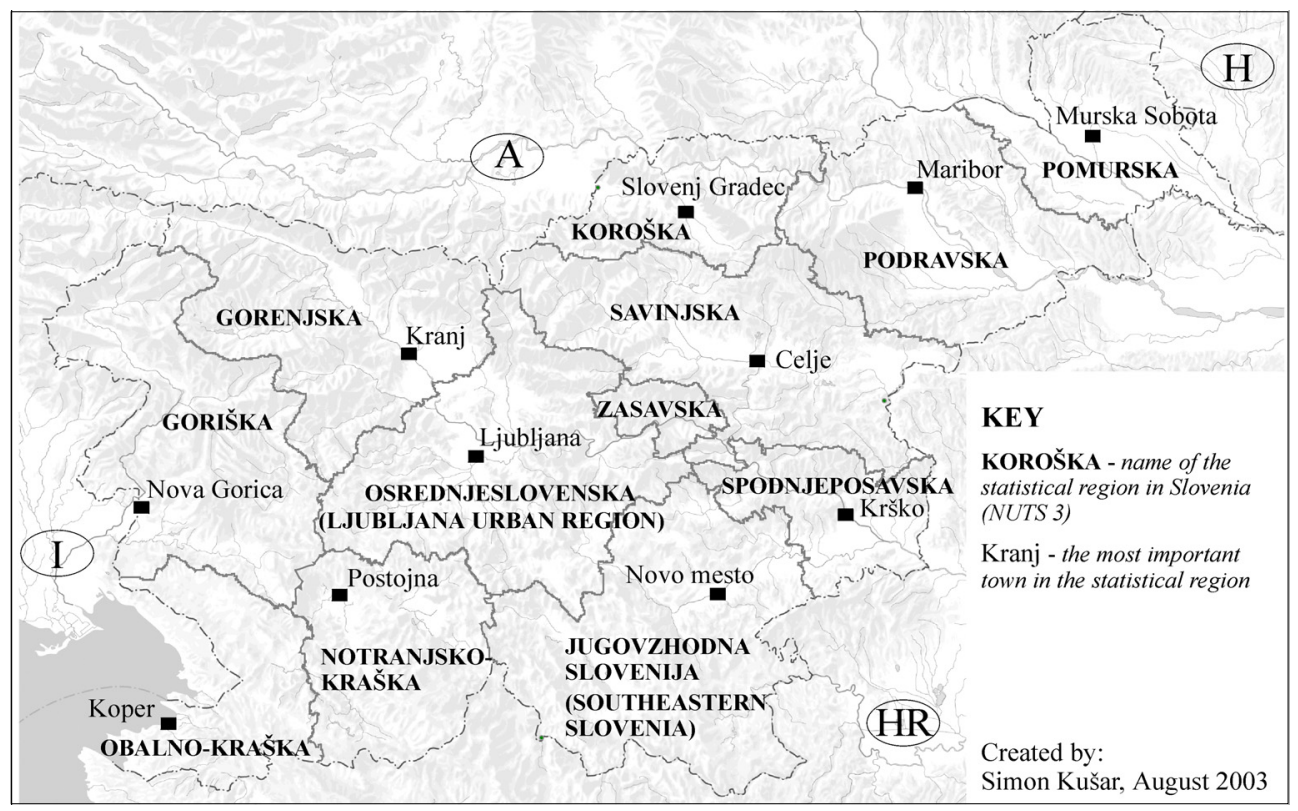




\section{THE ANALYSIS OF REGIONAL DEVELOPMENT PLANS}

\section{The Gorenjska statistical region}

Regional development programs and subprograms in operation up to 2006 anticipate the renovation of city centres. Larger influence on the function of cities and their functionalspatial structure shall have subprograms directed at solving the problems related to environment and infrastructure (e.g. road construction, sewage system and wastewater treatment plants) and improving degraded urban (industrial) areas. The access to town settlements shall improve by construction of new inter-regional roads, de-tours and inroads. A network of schools of higher education shall be established. The regional centre Kranj shall be formed, as well as a network of subregional centres with college degree schools and other services. Many programs and subprograms shall indirectly influence the improvement of human capital of the population in urban cities as well as their greater competitiveness at the labour market. The improvement of economic structure of cities is expected, especially by the development of small and medium enterprises in business and industrial zones. Urban cities shall be better protected from natural disasters.

\section{The Goriška statistical region}

Regional development shall be directed mainly toward the development of tourism and countryside. The perseverance of tertiary sector in all subregional centres is one of plan's basic starting points. Urban development and the hierarchy of central settlements are supposed to be defined in the sense of harmonised exercise of functions between certain settlements. Improved quality of life is expected by greater concern with health issues, taking measures against unemployment, raising the educational level (also by founding the university and college degree schools) and providing the all-life education. Further, a construction of industrial and business-tradesman's zones is expected as well as the improvement of degraded areas. Additionally, a construction of sewage system and wastewater treatment plant is anticipated. Public transport shall improve. Urban cities shall be more protected from natural disasters.

\section{The Jugovzhodna Slovenija (Southeast Slovenia) statistical region}

The executive part of this regional development program is very ample. Numerous programs and subprograms shall influence the further urban development at larger degree. A special importance is stressed to the development of the network of central towns. Novo mesto shall become a regional centre that entails the university and research-development centre, technological park, main regional institution and some special services. A network of subregional/local settlements with business-tradesman's zones, school centres and services shall be formed. New building sites shall be municipally regulated. Further, degraded urban areas shall get a housing and business function. Waste (solid or liquid) treat-ment shall 
improve. Human capital of citizens shall improve by better health conditions, education and personal growth.

\section{The Koroška statistical region}

In 2006, the urban settlements of Koroška statistical region shall improve their traffic function by finishing the construction of lacked transport lines and the development of service industry. The public transport shall be regulated. Business-tradesman's zone shall be built up. Traditional settling system shall persevere at simultaneous and proper territorial distribution of functions. The environment shall be less polluted. The quality of life shall improve by health protection practices, development of cultural activities and opportunities of selecting various sport activities.

\section{The Notranjsko-kraška statistical region}

Due to favourable geographical position of this region, many industrial and businesstradesman's zones shall be built up. Tourist infrastructure is planned to be developed in urban cities too (Postojna). An institution of higher degree education shall be founded. The improvement of degraded areas is expected as well as the salvation of some old environmental burdens through modernising and constructing the wastewater treatment plants, waste treatment, etc. In urban settlements, construction of housing buildings and maintenance of green-fields in the cities or at their suburbs shall increase. Remote heating system as well as gas pipes are planned to be initiated.

\section{The Obalno-kraška statistical region}

Regional development plan of Obalno-kraška statistical region shall have an important influence on the growth of urban cities too. Making some cycling tracks and pathways as well regulating the public traffic shall ensure sustainable mobility of citizens. Settlements shall be equipped by gas pipelines and sewage system. Waste treatment shall be initiated too. Programs and documents for revitalisation of city centres shall be prepared. Industrialbusiness and tradesman's zones shall be built up. Further, it is planned to develop the tourist infrastructure. Additionally, the educational level of citizens shall improve, also due to founding the university.

\section{The Osrednjeslovenska (Central Slovene) statistical region}

The regional development plan of most developed statistical region in Slovenia anticipates the improvement of sustainable mobility by investing into the network of tramlines. Waste shall be collected by its type and processed relevantly. Business zones and technological park are planned to be built up. Additionally, Ljubljana shall gain some regional institutions that are currently not in operation. 


\section{The Podravska statistical region}

The majority of their developmental programs and subprograms are directed toward the improvement of human resources, social development (health improvement, all-life education, the development of cultural activities, ensuring safe life, etc.) and economic growth. Urban settlements are supposed to have a good regulation of waste and wastewater treatment. The mobility of citizens shall be more sustainable due to anticipated regulation of public traffic and other forms of transport. Plots aimed at the development of new economic activities shall be defined. City centres shall be revitalised.

\section{The Pomurska statistical region}

The Pomurska statistical region wishes to solve numerous problems related to its development that is lagging behind. Therefore, most of regional development programs are directed toward promoting the economic growth by restructuring the existing industry, improving the effectiveness of agriculture and promoting the development of human resources. In urban settlements industrial, business and tradesman's zones as well as commercialtransport terminals shall be built up. Further, the waste treatment shall be regulated and polluted waters shall be cleaned. Additionally, the university degree study programs shall be established.

\section{The Savinjska statistical region}

The University degree study programs shall be established in the region, as well as business zones, development centres, and technological park. The system of public transport shall be regulated. Further, the sewage system as well as the wastewater treatment plants shall be built up. Waste shall be recycled. Alternative sources of energy are planned to be used. Urban settlements shall be more protected against floods.

\section{The Spodnjeposavska statistical region}

The urban settlements of Spodnjeposavska statistical region are to have organised concept of waste treatment regulation. Business zones and technological park are planned to be build up. Educational institutions offering higher level of education, including the university degree, are supposed to be established. Therefore, the educational level of citizens of Spodnjeposavje is expected to raise. Bigger urban settlements are to be equipped by gas pipelines. Settlements shall be protected from devastating waters. The speciality of this program is that it plans to prepare the spatial document, upon which the urban development is to be planned: empty places in the town settlements are to be filled up, depreciated and withered away industrial zone shall be reshaped, city centres renovated and revitalised. 


\section{The Zasavska statistical region}

Main developmental problems of Zasavje are linked to the old industrial structure and quitting the mining. Therefore, their regional development programs are directed to: strengthening the human resources, improving the educational structure, putting forward the all-life education practice, raising the employment and promoting the growth of small and medium enterprises. They are to provide the tradesman's and industrial zones. At larger urban settlements the system of gas supply and waste treatment system are to be provided. Wastewater treatment plants and canal systems are to be built up. Degraded urban areas shall be improved. The Faculty shall be established.

\section{CONCLUSIONS}

Based on the analysis of regional development programs and subprograms one may define their influence on transformation of urban settlement in Slovenia up to 2006 as follows:

- Spatial extension of cities, urbanisation: urban settlements are expected to be more densly built on the one hand and to spread out due to new constructions of roads, environment and economic infrastructure (road construction, building up waste and wastewater treatment plants, business, industrial and tradesman's zones, etc.) on the other hand;

- Functions of cities: the function of cities in the domain of traffic, education, living and services shall increase, especially in regional and subregional centres. Mining function shall disappear. City centres shall gain their meaning upon their revitalisation;

- Functional-spatial structure: new industrial, tradesman's, business and service zones and technological parks shall be built, historical city centres shall be revitalized. There shall increase areas aimed at traffic old industrial zones and other degraded urban areas shall be improved, new educational centres shall be formed, increased meaning of service industries (counselling, supportive, educational, business activities - further deindustrialisation) is to be expected;

- Morphological structure: the density of building construction shall increase, city cores shall be renewed. New morphological structural elements are to be introduced such as: islands for collecting waste by its type, gas stations, modern tradesman's-businessservice zones. Urban settlements shall expand. At this process, the modern ground plan shall prevail. The share of areas for traffic is expected to increase;

- Social and social-spatial structure: citizens of town settlements shall live in better health (the development of health-related activities, lessening the pollution in the cities), the level of unemployment shall decrease, and the problems of marginal groups shall be exposed for salvation. People are supposed to be more educated. The exact influence on social-spatial structure cannot be predicted from regional development plans. It should be examined on the basis of known data and models of social transformation;

- Meaning and influence of cities in the space: regional and subregional centres are expected to gain on their meaning, especially due to new educational and service func- 
tions. Cities shall be easily accessible due to construction of new roads, recon-struction of the railway and regulation of public transport;

- Relations between cities: regional and subregional centres are expected to be formed, territorial work differentiation is to be present.

According to regional development plans the network of regional and subregional centres in Gorenjska, Jugovzhodna Slovenia, Koroška and Pomurska statistical region is named. Defined subregional centres are not a surprise because they are comparative with the momentary network of central settlements of higher level. Only in Jugovzhodna Slovenia new relations between towns are going to be established since the western part of the statistical region used to be part of Osrednjeslovenska region. We can expect the exact definition of urban network in each statistical region in regional spatial plans, which are being prepeared right now.

Figure 2: Regional and subregional centres of Slovene statistical regions (NUTS 3) according to regional development programmes.

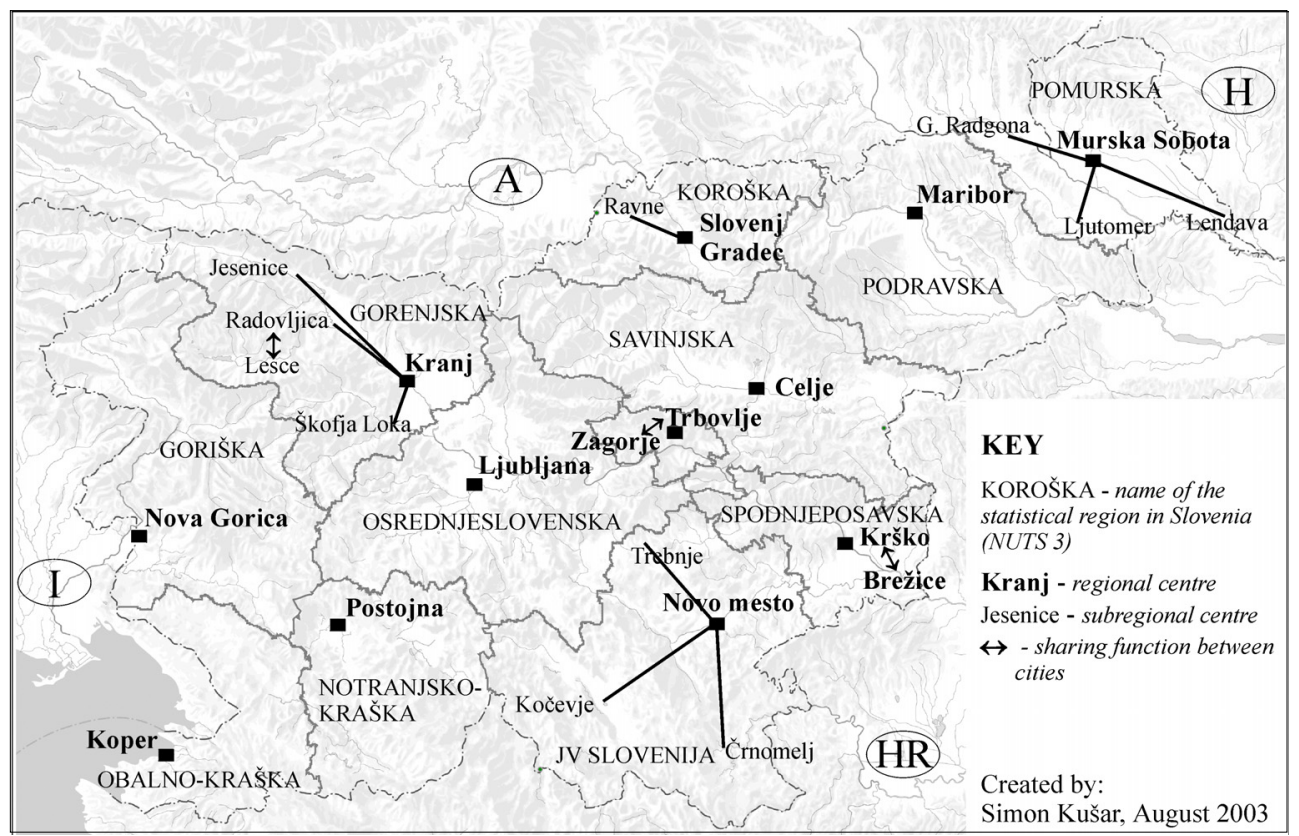

And how will Slovenian cities tomorrow look like? More sustainable. Degradation of environment shall decrease due to new constructions of sewage systems, wastewater treatment plants, as well as modern approach to waste treatment. Constant monitoring of achievements in the field of protection of the environment shall be introduced. Due to networks of gas pipelines, usage of alternative sources of energy, improved aqueduct, and increased usage of public transport, the usage of non-renewable sources and energy shall decrease. 
The quality of green field surfaces shall increase. Industry shall ecologise in para-llel with modern, environmentally sound forms of production based mainly on knowledge and innovation. Degraded surfaces shall improve. Settling shall be directed mainly to free areas inside of regulated zones of established settlements. Urban settlements shall be safer from natural disasters, especially from water. Citizens shall be more educated and in better health. They are supposed to feel safe and happy. The unemployment shall not be the main developmental problem anymore.

But will Slovenian cities in 2006 really look like that? Probably not entirely. The influence of regional planners and regional development programs on the transformation of cities is not final. Other processes and actors may dictate their reshapement too, like politics, businessman (Campbell and Fainstein, 1996), and especially city planners. At this point, the question on implementation of regional development plans seems to be relevant due to vagueness in the sense of time, organisation, cadres, content, legislation and politics.

Luckily, the future is still veiled and, as such, encourages us to actively participate at all spheres of social life.

\section{References}

Balanced Regional Development Act: Zakon o spodbujanju skladnega regionalnega razvoja. Uradni list RS, No. 60/99.

Campbell, S., Fainstein, S., 1996: Introduction: The Structure and Debates of Planning Theory. In: Readings in Planning Theory. Cambridge, Blackwell Publishers, 1-14.

Davidoff, P., Reiner, T. A., 1973: A Choise Theory of Planning. In: A Reader in Planning Theory. Oxford, Pergamon Press, 11-39.

Dror, Y., 1973: The Planning Process: a Facet Design. In: A Reader in Planning Theory. Oxford, Pergamon Press, 11-39.

Faludi, A., 1976: Planning Theory. Oxford, Pergamon Press, 306 p.

Friedmann, J., 1987: Planning in the Public Domain: From Knowledge to Action. New Jersey, Princeton University Press, $501 \mathrm{p}$.

Korelc, T., 2002: Spoznajte prihodnost in stopite na pot uspeha. Šmarješke toplice, Stella, $90 \mathrm{p}$.

Lah, A., 1999: Mesta so zgodovina in prihodnost. In: Mesta in urbanizacija. Zbirka Usklajeno in sonaravno. Ljubljana, Svet za varstvo okolja Republike Slovenije, $72 \mathrm{p}$.

Navodilo o minimalni obvezni vsebini in metodologiji priprave ter načinu spremljanja in vrednotenja regionalnega razvojnega programa. Uradni list RS, No. 52/00 and $111 / 000$.

Pečar, J., 2002: Regionalni vidiki razvoja Slovenije (in poslovanje gospodarskih družb v letu 2001). Delovni zvezki Urada za makroekonomske analize in razvoj, letnik XI, št. $7,159 \mathrm{p}$.

Premzl, V., 1999: Mesta in urbanizacija v Sloveniji. In: Mesta in urbanizacija. Zbirka Usklajeno in sonaravno. Ljubljana, Svet za varstvo okolja Republike Slovenije, 72 p. 
Regionalni razvojni program Gorenjske 2002 - 2006. 2002. Kranj, Regionalna razvojna agencija Gorenjske, 155 p.

Regionalni razvojni program Ljubljanske urbane regije za obdobje 2002-2006. Strateški in izvedbeni del programa. 2002. Ljubljana, Regionalna razvojna agencija Ljubljanske urbane regije, $155 \mathrm{p}$.

Regionalni razvojni program Notranjsko-kraške regije 2003-2006. 2002. Pivka, Regionalna razvojna agencija Notranjsko-kraške regije, $151 \mathrm{p}$.

Regionalni razvojni program Pomurje 2000+. 2002. Murska Sobota, Regionalna razvojna agencija Mura, $157 \mathrm{p}$.

Regionalni razvojni program regije Posavje 2002 - 2006. 2002. Krško, Regijski pospeševalni center Posavje, $133 \mathrm{p}$.

Regionalni razvojni program Savinjske statistične regije (končna in dopolnjena verzija). 2001. Celje, Regionalna razvojna agencija Celje.

Regionalni razvojni program statistične regije Goriška 2002 - 2006. Osnutek strategije. 2001. Idrija, Idrijsko-Cerkljanska razvojna agencija.

Regionalni razvojni program statistične regije Podravje. Predlog strateškega dela RRP za Podravje. 2002. Maribor, Mariborska razvojna agencija, 136 p.

Regionalni razvojni program za Južno Primorsko 2002-2006. Gradivo za programski odbor (predlog). 2002. Koper, Regionalna razvojna agencija Južna Primorska, 124 p.

Regionalni razvojni program za Koroško regijo. 2001. Ravne na Koroškem, A.L.P. Peca, $163 \mathrm{p}$.

Regionalni razvojni program za območje Jugovzhodne Slovenije (do leta 2006). 2002. Novo mesto, Podjetniški center Novo mesto.

Regionalni razvojni program za Zasavje. 2002. Zagorje ob Savi, Regionalni center za razvoj, $228 \mathrm{p}$.

Sarre, P., 1974: Planning the Future City. In: The Future of Cities. London, Hutchinson Educational, $355 \mathrm{p}$.

Sarre, P., Blowers, A., 1974: General Introduction. In: The Future of Cities. London, Hutchinson Educational, 355 p.

Trstenjak, A., 1993: Po sledeh človeka. Ljubljana, Založba Mladinska knjiga, 321 p.

Vresk, M., 2002: Grad i urbanizacija. Osnove urbane geografije. Zagreb, Školska knjiga, $252 \mathrm{p}$.

Vrišer, I., 1978: Regionalno planiranje. Ljubljana, Mladinska knjiga, 356 p. 